DOI: $10.2478 / \mathrm{v} 10014-009-0019-8$

Agrovoc descriptors: agriculture; plants, crops, domestication, genetic resources; biodiversity; environmental protection; agricultural situation; food security; quality of life; consumer behaviour

Agris category code: E50 S01 B50

\title{
Can we change stereotypes and improve the quality of life?
}

\author{
Marijan JOŠT ${ }^{1} *$
}

Received: May 14, 2009; accepted: July 27, 2009.

Prispelo 14. maja 2009; sprejeto 27. julija 2009.

\begin{abstract}
There are a number of generally accepted stereotypes. People base unsustainable behavior on some of them, thereby endangering their own species and all life on Earth. The most dangerous stereotype is that of the present as 'the century of science'. Actually, despite knowledge which doubles each year, thanks to globalization our generation will be the first in the history of humankind to lose more knowledge than it has gained. Based on a stereotype, human arrogance is endangering our existence on Earth. Mankind's treatment of the soil, water and air are clear examples, and this is discussed in detail. If people were to carefully recognize some stereotypes and discard them, the quality of life would gradually improve, and our striving for sustainability would be more realistic.
\end{abstract}

Out of approximately 250 thousand species of flowering plants, around three thousand are used by man for food. However, by far the largest amount of food for human beings is today supplied by a mere 20 different species. The small numbers of food crops make the human race quite vulnerable to environmental changes. Today, the variety of goods in the supermarket is largely superficial: the 1,500 articles that may be on display represent variations of only a few basic ingredients.

About ten thousand years ago, when people began harvesting the first domesticated plants, the Earth's human population was roughly four million. Today, that many people are born every ten days. If this trend continues after the year 2000 , we will have to grow as much food in the first two decades of the new century as was produced over the past ten thousand years.

In light of these facts, the possibilities of and prospects for sustainable agriculture as a principal source of food are discussed.

Key words: agriculture, plant domestication, genetic erosion, environment protection, alternative technologies

\footnotetext{
${ }^{1}$ JOST Seed-Research, Križevci, Croatia

* Report presented at $53^{\text {rd }}$ EOQ Congress - Cavtat, May 12-14, 2009
}

\section{ALI LAHKO SPREMENIMO STEREOTIPE IN IZBOLJŠAMO KAKOVOST ŽIVLJENJA? \\ IZVLEČEK}

Obstaja vrsta splošno sprejetih stereotipov. Pri netrajnostnem obnašanju ljudje izhajamo iz nekaterih stereotipov, pri tem pa ogrožamo obstoj svoje lastne vrste in življenja na Zemlji. Najbolj nevaren stereotip je, da naj bi bilo sedanje stoletje "stoletje znanosti”. Dejansko bo, kljub temu, da se obseg znanja vsako leto podvoji, naša generacija zaradi globalizacije prva $\mathrm{v}$ zgodovini človeštva, ki bo več znanja izgubila kot pridobila. Človeška aroganca ogroža naš obstoj na Zemlji. Naše ravnanje s prstjo, vodo in zrakom so jasni primeri, ki so v članku podrobneje prediskutirani. Če bi ljudje pazljivo stereotipe ugotovili in se tako po njih ne bi več ravnali, bi se kakovost življenja postopoma izboljšala in naša prizadevanja za trajnost bi bili bolj realistična.

Med približni 250 tisoč vrstami cvetnic se jih okoli tri tisoč uporablja za prehrano ljudi. Toda največji del naše prehrane daje samo 20 različnih vrst. Majhno število rastlin za prehrano pomeni, da je človeštvo ranljivo pri izpostavljenosti spremembam $v$ okolju. Danes je izbor izdelkov v supermarketih daleč presežen, med 1.500 razstavljenimi izdelki je le majhna variabilnost glede na nekaj temeljnih sestavin.

Pred približno deset tisoč leti, ko so ljudje začeli spravljati pridelke prvih gojenih rastlin so bili na Zemlji vsega okoli štirje milijoni ljudi. Danes se vsakih 10 dni rodi toliko ljudi. Če se bo ta trend nadaljeval tudi po letu 2000, bomo morali v prvem dvajsetletju novega stoletja pridelati toliko pridelkov, kot jih je bilo skupno pridelanih $\mathrm{v}$ zadnjih deset tisoč letih.

Glede na ta dejstva, možnosti in predvidevanja za pomen trajnostnega kmetijstva so $\mathrm{v}$ delu prediskutirana izhodišča za zagotavljanje glavnega vira prehrane.

Ključne besede: kmetijstvo, domestifikacija rastlin, genetska erozija, varstvo okolja, alternativne tehnologije 
A stereotype is a generalized, conventional and oversimplified perception, opinion, or image, based on the assumption of common attributes. It is a common form of social consensus, often a result of social engineering. Generally, it does not allow critical judgment. Let us examine some of them:

\section{DO WE GAIN OR LOSE KNOWLEDGE?}

Since Bacon's time $\left(17^{\text {th }}\right.$ century), the world's knowledge acquired through scientific endeavor was not merely the object of contemplation, rather it was put to work so that the human race could ultimately assume mastery and control over nature (Jones, 2005). Over the centuries, this has proved to be both right and wrong. Humankind has been improving its way of life by controlling nature, while at the same time it has been cutting the branch on which it sits.

Today, the general perception or belief is that we live in a century of science. In the past, human race never have had so many research institutions and researchers. Never before has so much been invested to explore and widen new horizons. As a result, the amount of knowledge doubles every five years, while in the field of genetics, the quantity of information doubles every two years (Rifkin, 1998). This is viewed as science marching forward, and anyone who isn't marching forward is a Luddite. Human beings have become arrogant. We have started to behave like a god, and believe that we can change, enhance and improve the world in which we exist.

And then suddenly we are shocked when we read: "In spite of the fact that our knowledge doubles each year, our generation is the first generation in the history of the world to lose more knowledge than it has gained."(Mooney, 2001).

You will argue: No, that's impossible! The revolutions in different areas of science are changing faster and faster: after the revolutions in chemistry, physics, genetics, information technology, and biotechnology, now we are approaching a new revolution in nanotechnology. All this has happened in less than two centuries. (Two decades ago there were no nanotech patents at all. Today, the U.S. Patent Office alone grants more than 150 patents per year. According to the Organization for Economic Co-operation and Development (OECD), governments are now spending over $\$ 1.5$ billion per annum on nanotech development.) If so, how do we accept this nonsense about lost knowledge?

Let me explain: Due to globalization, the forces eroding our eco-systems, human cultures, and societies are tremendous. In the last century, due to globalization, almost half of the world's languages disappeared (in one-third of Latin America there are no indigenous languages spoken), and half of those remaining will vanish with the current generation.

The joint report of the Dag Hammarskjöld Foundation Uppsala, and the Rural Advancement Foundation International - Winnipeg, "The ETC Century Erosion, Technological Transformation and Corporate Concentration in the $21^{\text {st }}$ Century" argues that, with the erosion of language comes the erosion of our traditional knowledge of the eco-system and our capacity to adapt to climate change and other environmental pressures. It encapsulated the basic knowledge of life and survival collected trough millions of years of evolution transferred from generation to generation. With the extinction of languages, this knowledge is also forgotten (Mooney, 2001). For example: traditional healers along with language, the knowledge of medical preparations and treatments were lost for ever. Or: The former Andean culture perceives "nature" as a living and highly sensitive being, capable of responding positively when handled well, but also of responding furiously when mistreated. (Paul et al., 2003) While contemporary science across disciplines is once more rediscovering how nature is organic, dynamic and interconnected (Ho and Ching, 2003), some contemporary scientists express the opinion that "Nature is wild, has no brain and man should improve it."

However, the prefix scientific for modern systems, and unscientific for traditional knowledge systems has less to do with knowledge and more to do with power.(Shiva, 2000) Science has never been more powerful than it is today, and in the future it will be able to do much more than it will be allowed to do (Koshland, 1996). The scientist, by making observations of selected parts or elements of reality, seeks to uncover causal connections between them within the framework of universally applicable laws and theories. Priority is thus given to the parts over the whole (Jones, 2005). Instead of applying a holistic approach, science is becoming increasingly reductionistic.

As critical elements for human survival, powerful new technologies are being brought forward to manipulate our world, exposing them to the possible collapse of our biological environment and our cultural diversity. I am afraid the near future will confirm this. 


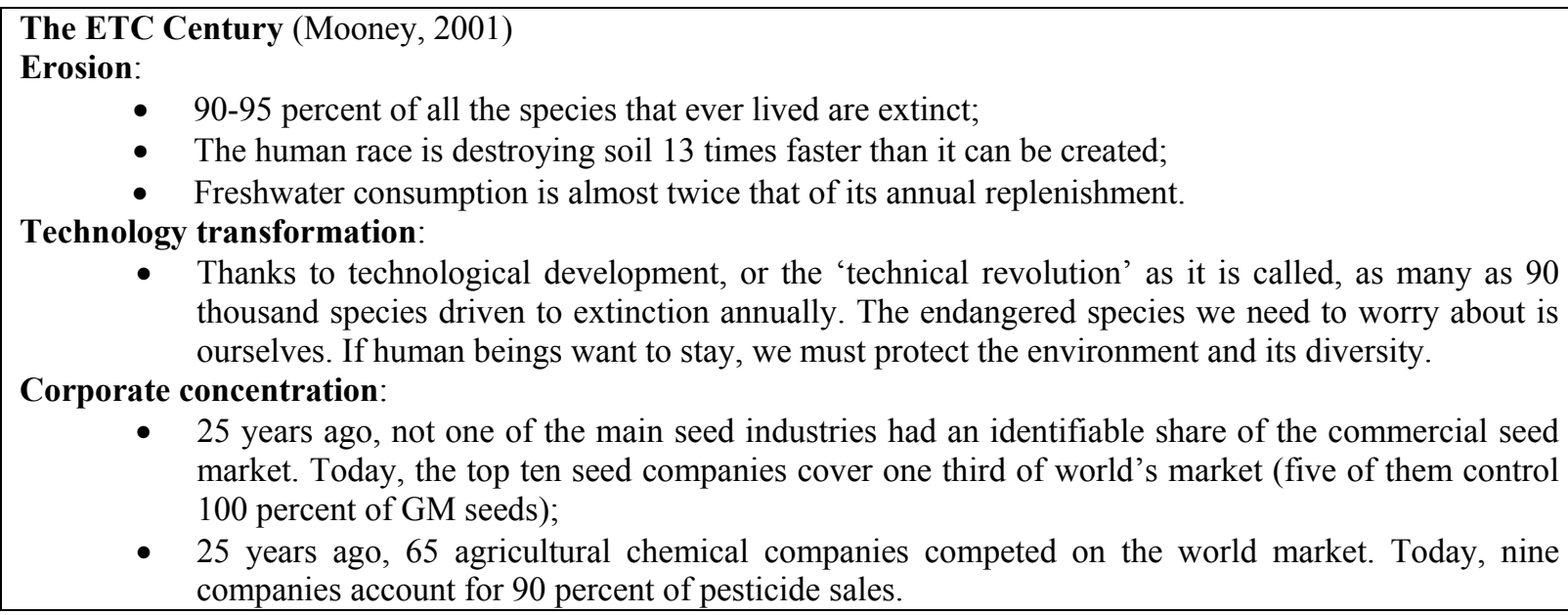

Science and technology have produced too many unintended side effects on the environment and society, and if the present economic dynamics continues, the final result will be ecological catastrophe (Supek, 1971). Today, as never in the past, the vision of world catastrophe calls for an intervention of common sense (Supek, 1999). Even without the scientist's warnings, it should be clear that we cannot endlessly and unsustainably exploit our habitat resources for shortterm economic gain (Schlickeisen, 1992).

In 1847, Justus von Liebig discovered that nutrients removed from the soil by crops could be replaced by minerals in specific rock formations. There are just a few honest scientists like him. The inventor of chemical agriculture, when looking back on his own life and work wrote: "I have signed against the wisdom of the creator and, justly, I have been punished. I wanted to improve his work because, in my blindness, I believed that a link in the astonishing chain of laws that govern and constantly renew life on the surface of the Earth had been forgotten. It seemed to me that weak and insignificant man had to redress this oversight." (From: Agrikulturchemie, 8. Auflage, 1865).

Where are the responsible scientists today? Science without responsibility can be extremely dangerous. If the scientist is dishonest, untruthful, fraudulent, or excessively self-interested, the free flow of accurate information so essential to science will be thwarted (Comstock, 1994).

\section{IN THE HISTORY OF CIVILIZATION THE PLOUGHSHARE HAS BEEN FAR MORE DESTRUCTIVE THAN THE SWORD}

This is another surprisingly statement made by Hillel (1991). At first look, it is difficult to believe. But let me explain the facts:

Conversion of natural ecosystems into agricultural ones began ten thousand years ago when our ancestors started to cultivate plants for food. In the beginning, this transformation was slow, occurring only in scattered localities and posing no threat to the wider ecosystem. Naturally created "virgin" soils remained essentially intact until the plow was developed. In time wooden plows were replaced by metal ones, and beasts of burden were used to pull them. In 1837, John Deere began to sell his all steel moldboard plows pulled by horses. Two decades later, a steam engine was used to pull the plow, and by the 1930 s, over a million tractors did the job. All this new machinery accelerated the demise of virgin soils (Warshall, 2000).
As early as the fourth millennium BC, Mesopotamia "the land between the rivers," the Tigris and Euphrates, is widely acknowledged as the "Cradle of Civilization". A warm climate, rich alluvial soils and the availability of a permanent water supply from the rivers gave rise to the development of agriculture among the people of Sumer, Akkad, Babylonia, and Assyria. Since the same plots of land could be cultivated year after year, hunting and gathering societies were replaced by permanent settlements. The availability of surplus food production was probably the most important factor that allowed some members of this society to engage in art and inventions (domesticated animals, the wheel, the wagon, cities, writing, money, etc.). Surplus food deserved the credit for the cultural development of this society (Davis, 2002; Jackson, 2000; Kimbrell, 2000; Warshall, 2000).

Acta agriculturae Slovenica, 93 - 3, september 2009 
But not forever. After about three thousands years of growth, this famous civilization disappeared. Why? Besides increasing crop yields, irrigation was destroying the soil by bringing and depositing tremendous amounts of soluble salts. The three millennia of excessive salinization converted the fertile soil into sterile, not suitable for growing any crop. When soil erosion is in question, the history of the Phoenician, Greek, Carthaginian, and Roman civilizations was quite similar.

The great Plato witnessed land degradation and its consequences, and in one of his dialogues, he proclaimed: "...what now remains of the formerly rich land is like the skeleton of a sick man, with all the fat and soft earth having wasted away. The plains that were full of rich soil are now marshes." (Jackson, 2002).
Learning from history, we can conclude: Every nation that fell did so not only due to political reasons but because their agriculture policies failed (Branden, 2002). Does history repeat itself today? The answer is a categorical YES.

The major conflict between conventional and alternative agriculture in the coming century will involve concern over environmental degradation (Hartel, 1994). To preserve the integrity of the environment, we should be able to apply a holistic approach (which stresses love, compassion and respect for nature) instead of a utilitarian approach ("pesticide use increases yields"), or rights-based ones ("we have the right to use water just as we have always done").

\section{Energy}

1. In the USA, 17 percent of total energy consumption are spent for production and distribution of food inside the country.

2. For each energy unit of food on our table, ten energy units were spent in production, and additional thousand energy units in food processing.

3. 12.5 energy units were spent per thousand miles in air transportation of each energy unit of food - more than in production of those food.

4. Organic agriculture permits 2-10 times energy saveing.

Chemical farming technology originated from military use during the twentieth century. Commercial fertilizers became a big business after World War I, as pesticide production did after WW II. The processes and chemicals created in the war were turned into fertilizers and pesticides (Paul et al., 2003). Since 1950, insecticide usage in the US has increased from 8 million kilograms to more than 57 million $\mathrm{kg}$ (Jackson, 1985). Their production requires energy. At the end of the twentieth century, farmers used more than 160 liters of oil on average to produce 1 ton of grain. This means it uses more energy than it produces (Comstock, 1994). Today, industrial agriculture uses up to ten times more energy per ton of produced food than organic farming.

Water

World Commission on Water for the $21^{\text {st }}$ Century quotes:

- $1 / 2$ of the world's rivers and lakes are seriously contaminated by human activities.

- $20 \%$ of total rainfall covers the Amazon River basin with only 10 million inhabitants.

- Due to a lack of water, in 2020 the world agricultural production will be reduced to an amount equal to today's production in the United States

- Competition for water between cities, industry and agriculture will increase: in 1950 there were less than 100 cities with over million inhabitants; according to forecasts, in 2025 there will be roughly 650 cities of this size $1 / 2$ of the world's population will live in cities

Today, we grow twice as much food as a generation ago, but we use three times more water to do so. Approximately 70 percent of all water used by humans is for crop irrigation. Irrigation of food and livestock feed crops contributes to salinization, an irreversible process accelerated by global warming. Groundwater supplies in major agricultural regions are being, depleted at a much faster rate than their replenishment by rainfall. Every teaspoon full of sugar in your coffee requires 50 cups of water to grow sugar, and 1,120 cups of water to grow coffee (Fowler, 2006).

Different crops require different amounts of water, and some of them are more productive. For instance: with the same quantity of water, sorghum yields 4.5 times more proteins, 4 times more minerals, 7.5 times more calcium, 5.6 times more iron, and 3 times more food than rice (Shiva, 2006). 
Today, industrial agriculture turns organic soil, which is a carbon sink, into a carbon source, and generates other green-house gases that exacerbate global warming. (According to the Union of Concerned Scientists <www.ucsusa.org>, since 1995 we have experienced the hottest twelve years on record since 1880.)

Soil (Warshall, 2000)

- Soil is literally alive with a networked complexity greater than that of human brain tissue.

- The number of living creatures (species) is much greater below than above the soil's surface.

- More microbes live in a teaspoon of soil than people on the planet.

- A few centimeters of one square meter fertile topsoil might contain: a thousand each of ants, spiders, beetles and their larvae, two thousand each of earthworms, myriapods, eight thousand snails, 20 thousand pot worms (Enchytraeids), 40 thousand springtails (Collembolas), 12 million nematodes, 20 million fungi and 5 billion bacteria.

Moreover, earlier research conducted by Iowa State University (1972) estimated that as a result of industrial agriculture, the largest agricultural producer, the United States is losing over four billion tons of soil annually. As an illustration, rendered as freight cars, this would form a train that could encircle the planet twenty-four times (Jackson, 1985). This means that for each ton of exported agricultural goods, 2.5 tons the most fertile surface soil (about 20 tons of soil/hectare/year) are lost by wind or water erosion (Comstock, 2001).

Desertification is becoming a serious threat, and some scientists are forecasting the collapse of American agricultural production within the next half century. The time will soon come when North America will import nearly all agricultural products from less developed countries abroad (Blank, 1998). In the last century, the transformation and disruption of the world-wide environment have become faster and more pronounced. The ancient civilization of Mesopotamia needed three thousand years to reach the same level of soil destruction, while modern Americans will do the same in less than two centuries. Frightening! But the US is not the only example. Desertification in some regions of China is also troubling. Sand dunes lie only 70 miles from Beijing, and they are approaching at a speed of over 3 miles per year.

As Ellen Davis (2002) wrote: "The first eleven chapters of Genesis, that dirty history of early humankind, is in fact the story of dam's progressive alienation from God and fertile soil. Almost every page of the Old Testament sheds light on our relationship to the earth's topsoil, who knows? Maybe today's sad statistics on soil loss will become a religious issue."

\section{THE BIOETHICS OF FOOD PRODUCTION}

There are moral and bioethical concerns. The things now wrong with agriculture all come from the human willingness to manipulate nature, i.e. to convert health into wealth (Jackson, 1985). Not so recent reports suggest that billions of people in the world could be fed with the food produced by new wonder cultivars and industrial agriculture technology.(Avery, 1985) At the same time, other reports suggest that industrialized agriculture is not sustainable because of its impact on the world's resources and environment - air, water, soil and biological diversity (Blatz, 1994).

It is up to you to decide which is the right way to follow. The decision is not easy, but is fateful. Sustainable agriculture is closely correlated with moral sustenance.
In order to feed the world, we must invest in sustainable agriculture across the globe, which will also ameliorate the worst consequences of climate change (Ho and Ching, 2003).

Dr T. R. Preston, Director of theUniversity of Tropical Agriculture Foundation in Phnom Penh, Cambodia explained: „As long as 'farmers' (more so those in agribusiness) continue to feed half the world supply of grain to livestock to produce food which is subsidized, for consumption by people most of whom are over-fed, and many of them severely obese, there is no basis for justifying GM technology as a necessary means to save the world's poor from hunger. 


\section{CAN AGRICULTURAL DEVELOPMENT BE SUSTAINABLE?}

This is a difficult question and the answer depends upon the period under observation. Two items are critical:

1) Population growth: Consider that during the second millennium, each doubling of the population took roughly half as long as the previous doubling. In the nineteenth century, global population growth was 0.672 billion, while in the twentieth century it was 4.4 billion (a 6.5 fold increase).

How far can this population increase go? In order to secure the foods supply, should humankind be forced to control it?

Table 1. Global population growth per century (in billions)*

\begin{tabular}{|l|c|c|c|c|c|}
\hline Year & 1800 & $19^{\text {th }}$ century & 1900 & $20^{\text {th }}$ century & 2000 \\
\cline { 1 - 5 } Population & 0.978 & & 1.650 & & 6.050 \\
\cline { 1 - 3 } Growth difference per century & & 0.672 & & 4.400 & \\
\hline
\end{tabular}

2) Environmental degradation: As it was proven by history, technologies can solve problems, but can create new (bigger) ones as well. Powerful new technologies are being brought forward to manipulate our world. Science and technology has produced too many unintended side effects on the environment, changing it in an undesirable way. The speed of these changes is increasing rapidly, while most scientists have been "social sleepwalkers" - avoiding the social impact of their research while benefiting from commercialization (Mooney, 2001).

In June 2001 at Göteborg, the European Council, in order to create a sound balance between knowledgebased economic growth and environmental and social needs, discussed the European Strategy for Sustainable Development. It states: "The Common Agricultural Policy and its future development should, among its objectives, contribute to achieving sustainable development by increasing its emphasis on encouraging healthy, high quality products, environmentally sustainable production methods, including organic production, renewable raw materials and the protection of biodiversity."(EC, 2001; EC 2007). Nice words. However, in spite of the fact that sustainable development is accepted as a fundamental objective of the European Union, after six years the conclusions of the Progress Report (October 2007) of the European Council shows that progress on the ground has been modest (EC, 2007).

On April 15, 2008, 400 scientists in the International Assessment of Agricultural Science and Technology for Development (IAASTD) released a 2,500-page report that took four years to complete (IAASTD, 2008). Its conclusions were: Natural resources (soil, water, biological diversity, vegetation cover, renewable energy, climate, and ecosystem services) are fundamental for the structure and function of agricultural systems and for environmental sustainability. It calls for a fundamental change in farming practices to counteract hunger, poverty and environmental disasters. It recognizes the importance of traditional and local knowledge - knowledge-generating capacity that is needed if sustainability and development goals are to be achieved (IAASTD, 2008).

Obviously, today sustainable development has become a hot topics acknowledged by politics and science. But I am afraid that, observed over a longer period (thousands of years), sustainable development is an illusion. Farming doesn't work the way nature does: it doesn't create its own self-replenishing cycle. Today, the development of human society is at the expense of the environment and biological diversity, and cannot be sustainable.

However, there are more optimistic views. The creator of Dream Farm 2, Mae-Wan Ho was inspired by two ideas: 1) The "circular economy" of Japanese farmer Takeo Furano works perfectly on his 2 ha farm. The system is absolutely dependent on the natural biodiversity of species working to benefit one another: ducklings to work in paddy fields, resulting in harvests of 7 ton of rice, 300 ducks, 4,000 ducklings, countless fish, and enough vegetables for 100 people. Best of all, he and his family get plenty of free time from not having to do any weeding, because the ducklings eat all of the weeds and pests. The ducks not only eat the weeds and pests, they fertilize the water to feed the rice plants, the rice plant attract pests, which make more food for the ducks. The ducks also feed the plankton in the water, which feed the fish, and sometimes fish fries get eaten by the ducks. The circular economy system works by reciprocity and mutual benefit (Ho et al., 2008).

2) The "Integrated Food and Waste Management System" of Professor George Chan. The biogas digester 
is the heart of the system, and it reinforces the circular economy and makes it more efficient. In the biogas digester, livestock manure and other organic waste are converted into biogas (60 percent methane), which can provide all of the energy needed for cooking, heating, electricity and processing. The residue in the digester is rich compost. The system relies entirely on internal input, recycling all of the waste and turning waste into food and energy resources. This approaches the ideal of the sustainable system, which operates like an organism.
The large lifecycle consists of many different cycles of activities coupled together and working together. The more lifecycles that are linked into the grand cycle, the more productive the land, and activities that yield energy are directly linked to those requiring energy, and all of the cycles feed one another. In this Dream Farm 2, a wind, hydro and solar energy could be included also, where appropriate (Ho et al., 2008).

\section{CONCLUSION}

What is right and acceptable is what produces good consequences: access to basic human needs, sustainability to protect future generations, and protection of biodiversity (Blatz, 1994). The main question is: how agriculture can feed the world today, and maintain sustainability for tomorrow. In the coming century, the major conflict between industrialized and traditional agriculture will be the concern for environmental degradation, and industrialized agriculture will be forced to adopt some traditional agriculture practices (Hartel, 1994). In this sense we can distinguish two main types of agriculture:

1) Agriculture as business (industrialized, conventional agriculture) - If we accept agriculture as business, then we should accept all of the accompanying phenomena:

- competitiveness (speed, quantity, profit),

- centralization (control of land resources and capital), and

- $\quad$ specialization (narrow field products dependent on science and technology).

The only values considered are yields; the cost and impact of pesticides and fertilizers on soil, water, biological and agricultural diversity, and human health are discounted or externalized (Paul et al., 2003). The engine that drives agriculture-asbusiness is profit, and its philosophy is investment of capital in order to get the highest possible return. But, land and water degradation, as well as loss of biological diversity, are not considered as an economic loss. This agriculture is not sustainable and cannot last forever. It is not primarily concerned with continuing to use the same resources now and in the future. Industrialized agriculture favors the momentary (not lasting) goods of human well-being over those of ecological integrity and non-human welfare (Aiken, 1984).

2) Agriculture as a way of life. Alternatively, we may regard agriculture not as business, but as a way of life. In that case, its characteristics are:

- community (emphasis on permanence, quality, and beauty),

- decentralization (dispersed control of land, resources, and capital),

- non-specialization, and

- emphasis on personal knowledge and local wisdom (Beus et al. 1991).

Agriculture as a way of life is labor-intensive rather than capital and technology intensive, oriented to the local market, more diverse, and more organic. It respects Mother Nature and is more sustainable.

It is not hard to understand which of the approaches to agriculture must be followed if we are to survive as a species. The values of agriculture for the next century must be:

a) Health of the land

b) Welfare of future generations

c) Social and interspecies justice and

d) Integrity in meaningful work and relationships (Freudenberger, 1986).

The father of modern taxonomy, Carl von Linné - the man who gave us the binomial system of nomenclature also gave us our name: Homo sapiens. Sapiens means wise, sage, or knowing. Did the great Linnaeus get it right? That is up to us. It depends on whether we solve our oldest environmental problem - the problem of agriculture (Jackson, 2000). 


\section{REFERENCES}

Aiken, W. 1984. Ethical issues in agriculture. In T. Regan (ed.); Earthbound: New introductory essays in environmental ethic. Random House, New York, p. 247288.

Avery, D. 1985. U.S. farm dilemma: The global bad news is wrong. Science, Washington DC, 230:408-412.

Beus, C.E., R.E. Dunlap, R.M.Jimmerson, and W.L. Holmes. 1991. Competing paradigms: The debate between alternative and conventional agriculture. Res. Bull.XB1020. Washington State University, Pullman.

Blank, S.C. 1998. The End of Agriculture in the American Portfolio. Quorum Books, p.232.

Blatz, C.V. 1994. Coming full circle: Ethical issues in traditional and industrialized agriculture. In: P.G.Hartel et al. (Eds) Agricultural ethics: Issues for the $21^{\text {st }}$ century. ASA Spec. Publ. No.57, pp. 33-42.

Branden, N.P. 2002. The letter to David Kendra, USDA, Tulare, August 18.

Commission of the European Communities. 2001. A Sustainable Europe for a Better World: A European Union Strategy for Sustainable Development (Commission's proposal to the Göteborg European Council). Brussels, May 15. http://europa.eu/eurlex/en/com/cnc/2001/com2001_0264en01.pdf

Commission of the European Communities.2007. Progress Report on the Sustainable Development Strategy 2007. Brussels, 22.October. http://ec.europa.eu/ sustainable/ docs/com_2007_642_en.pdf

Comstock, G. 1994. Some virtues and vices of agricultural technology. In: P.G.Hartel et al. (eds) Agricultural ethics: Issues for the $21^{\text {st }}$ century. ASA Spec. Publ. No.57, pp. 25-32.

Comstock, G. 2001. Ethics and genetically modified foods. SCOPE GM Food Controversy Forum, July $1^{\text {st }}$. $<$ http://scope.educ.washington.edu/gmfood/>

Davis, F. Ellen. 2002. The Bible and our topsoil. Prairie Writers Circle, Cropchoice, November 11,

Fowler, C. 2006. The genetics of water, Global crop diversity trust. http://www.croptrust.org/documents/newsletter/ newsletter_croptrust_v1_final.htm

Freudenberger, C.D. 1986. Value and ethical dimensions of alternative agricultural approaches: In quest of a regenerative and just agriculture. In K. Dahlberg (ed.): New directions for agriculture and agricultural research: Neglected dimensions and emerging alternatives. Rowman \& Allanheld, Totowa, NJ, p. 348-364.

Hartel, P.G. 1994. Overview. In P.G. Hartel et al. (eds.), Agricultural ethics: Issues for the $21^{\text {st }}$ century. ASA Special publication No.57:1-10.

Hillel, D.J. 1991. Outh of the Earth: Civilization and the life of the soil. Free Press, New York. NY, USA.
Ho, M.W. and J. Cummins. 2001. The unnecessary evil of 'therapeutic' human cloning. ISIS Report Jan.; ISIS News \#7 http://www.i-sis.org/stemcells-pr.shtml

Ho, M.W and Lim Li Ching. 2003. The case for a GM-free sustainable world. Institute of Science in Society \& Third World Network, London and Penang, p. 115.

Ho, M.W., S. Bucher and Ching L.L. 2008. Food Futures Now. ISIS \& TWN, p. 178.

International Assessment of Agricultural Knowledge, Science \& Technology (IAASTD) Synthesis Report 25 November 2007, http://www.agassessment.org/docs/ Synthesis Report_261107_text.pdf

IAASTD. 2008. Executive Summary of the Synthesis Report of the International Assessment of Agricultural Knowledge, Science and Technology for Development. Johannesburg, South Africa, 7-11 April. Island Press, p.24. http://www.agassessment.org/docs/IAASTD_ EXEC_SUMMARY_JAN_2008.pdf

Jackson, W. 1985. New roots for agriculture. University of Nebraska Press, Lincoln-London, p. 150.

Jackson, W. 2000. Acceptance Speech. The Right Livelihood Awards, December $8^{\text {th }}$. http://www.rightlivelihood.org/ jackson_speech.html

Jackson, W. 2002. Natural Systems Agriculture: A radical alternative. Agriculture, Ecosystems and Environment, Vol. 88, pp. 111-117.

Jones A. 2005. Mutualism and Interdependence: a Gaian critique of Science and Society. $1^{\text {st }}$ Southeast European Bioethics Forum, Mali Lošinj, June 16-18. (Personal communication)

Kimbrell A. 2000. Water - The overtapped resource. In: A. Kimbrell (ed.) Fatal harvest - The tragedy of industrial agriculture. Island press, Washington, Covelo, London, pp. 229-234.

Koshland, D.E. 1996. Ethical decision making in a pluralistic society. In: F.B. Rudolph and L.V. McIntire (Eds.) Biotechnology: science, engineering and ethical challenges for the twenty-first century. Washington. p.p. 191-198.

Mooney, P.R. 2001. The ETC Century - Erosion, technological transformation and corporate concentration in the $21^{\text {st }}$ century. Dag Hammarskjöld Foundation, Uppsala, and Rural Advancement Foundation International, Winnipeg, p. 128

Paul, Helena, Richarda Steinbrecher, D. Kuyeke and Lucy Michaels. 2003. Hungry corporations. Transnational biotech companies colonise the food chain. Zed Books, London \& New York, p. 242.

Pimbert, M. 2009. Towards Food Sovereignty - Reclaiming autonomous food systems. International Institute for Environment and Development, London, p.63. 
Presidency Conclusions. 2001. European Council Göteborg. 15 and 16 June. http://www.europarl.europa.eu/summits/ pdf/got1_en.pdf

Rifkin, J. 1998. Harnessing the gene and remaking the world The biotech century. Tarcher - Putman, New York, p.271

Schlickeisen, R. 1992. The earth ethic. Defenders Magazine, Nov./Dec. $<$ http://www.defenders.org/rsnd92.html>

Shiva Vandana. 2000. Monocultures of the mind. TWN, Malaysia, Zed Books Ltd. London and New York, $\left(4^{\text {th }}\right.$ eddition) p.184.

Shiva, Vandana. 2006. Ratovi za vodu - Privatizacija, zagađivanje i profit. DAF, Zagreb, p.177.
Supek, I. 1971. Spoznaja. Mladost, Zagreb.

Supek, I. 1999. Mene Tekel Fares. Naklada MD, Zagreb.

Warshall, P. 2000. Tilth and technology - The industrial redesign of our nation's soils. In: A. Kimbrell (ed.) Fatal harvest - The tragedy of industrial agriculture. Island press, Washington, Covelo, London, pp. 221-228.

\section{Author address:}

Marijan Jost < marijan.jost@kc.t-com.hr > Stjepana Radica 21

48260 Krizevci, Croatia 